Journal of Life Economics

Cilt / Volume 7, Say1 / Issue 2, 2020, pp. 151-160

E - ISSN: 2148-4139

URL: https://www.ratingacademy.com.tr/ojs/index.php/jlecon

DOİ: https://doi.org/10.15637/jlecon.7.010

Araştırma Makalesi/Research Article

\title{
THE CHANGE IN THE MANAGEMENT STRUCTURE OF MEDIA INSTITUTIONS IN THE FOURTH INDUSTRIAL REVOLUTION (INDUSTRY 4.0) PROCESS
}

\author{
Birol AKGÜL * \& Zeynep AYER ** \\ * Assoc. Prof. Dr., Çanakkale Onsekiz Mart University, Communication Faculty, \\ Çanakkale/TURKEY, e-mail: birolakgul@hotmail.com \\ ORCID: https://orcid.org/0000-0002-0701-0928 \\ ** Research Assistant, Çanakkale Onsekiz Mart University, Communication Faculty, \\ Çanakkale/TURKEY, e-mail: ayerzeynep@gmail.com \\ ORCID: https://orcid.org/0000-0003-4107-0171
}

Received: 24 March 2020; Accepted: 17 April 2020

\begin{abstract}
Industry 4.0 refers to the latest development of industry, which began in the 18th century in England. In this period, the industrial sector, which has passed through three important stages with the use of steam power, electricity and computer in industry, is facing the fourth stage, called Industrial 4.0, or the Fourth Industrial Revolution, with the emergence of the concept of $i$ the Internet of things ". The fact that objects reach the internet and communicate with other devices, in other words, objects become "smart objects Nes has brought the concept of the Internet of objects into the agenda. Intelligent objects have a place in daily life; The mechanization of production in the agricultural, industrial and service sectors is thus interpreted as minimizing the need for human beings. The situation shows that there will be radical changes in the working principles of the sectors. The change in the production method and the need for human beings bring the questions about how the management structures of the enterprises will continue. It is envisaged that the mechanization of Industry 4.0 will be highly effective on the service sector, which is a labor-intensive sector, and the enterprises operating in the sector. In this study, it is aimed to discuss the possible changes in the management structures of the organizations operating in the media sector which are sub-sectors of the service sector during the Industry 4.0 process. In the study, the concept of Industry 4.0 was first defined and its scope was analyzed. Then media organizations and management structures were examined. Finally, evaluations and projections regarding the possible change of the management structure of media organizations within the scope of Industry 4.0 are given. Literature review and editing methods were used in the study.
\end{abstract}

Keywords: The Fourth Industrial Revolution, Industry 4.0, Media Institutions

Jel Codes: L22, L82, M10 


\section{INTRODUCTION}

Terms sustainability and inovation gained prominence in recent years in academic research. According to Uzkurt (2010: 37), the basic dynamics of innovation constitute "innovations that are transformed into or transformed into an economic and social added value." Harris (2000: 3) thinks that sustainability can be defined economically as a maximization of welfare.

2018 Global Competitiveness Index (WEF, 2018: 14) by, while Turkey ranked 61st among 140 countries in 2017 (WEF, 2017: 11) seems to be \# 53 of 137 countries. According to the report, Turkey is in the category of developing countries. The 2018 report details the evaluation, gradually increased global competition today, it said that Turkey should take several steps in.

The importance of the real economy was understood with the global financial crisis that started in the USA in 2008 and was effective globally. Developed countries affected by the crisis have developed policies towards re-industrialization in order to revive production. These policies are not designed to improve standard production methods, but to establish a system for digital production based on information technologies.

In addition to these, "Fourth Industrial Revolution" or "Industry 4.0" is talked about, especially in Germany, USA and many developed countries. Industry 4.0, which came to the fore in 2011 and has gained popularity every day, has the potential to influence all sectors of the economy. If Industry 4.0 is fully implemented, it is thought that economies that cannot complete their structural transformation will not have a voice in the world. Therefore, the new framework to be drawn by Industry 4.0 should be taken into consideration in future plans, projects, R\&D and investment planning. In this study, the media sector, which is one of the sub-components of the service sector, is discussed. Purpose of the study is to discuss the possible changes in the management structures of media organizations in Industry 4.0 process. The study consists of three main sections. In the first part, the concept of Industry 4.0 is discussed. In the second part, media organizations, types and existing management structures are examined. In the last part, the predictions regarding the possible change and transformation of the management structures of media organizations in Industry 4.0 process are given.

\section{THE CONCEPT AND THE SCOPE OF THE FOURTH INDUSTRIAL REVOLUTION (INDUSTRY 4.0)}

Industry 4.0, which forms the basis of the study, is discussed in this section. First of all, a conceptual explanation of Industry 4.0 was made and the elements on which it was based were examined. Then, the applicability, advantages and disadvantages of Industry 4.0 are discussed.

\subsection{Industry 4.0}

Nowadays, traditional forms of production are entering a digital transformation process with the effect of continuously developing technology. Altuntaş (2018: 8) defines digital transformation as brands use technology in all their processes to keep up with digital time. Digital transformation is supported by the Internet of Things (IoT), sensors, smart robots, cloud technologies and big data. The transformation, which envisages the cooperation of industry and information technologies, is called "Industry 4.0".

Inception of Industry 4.0 or the Fourth Industrial Revolution, begins with Kagermann article dated 2011(Alçın, 2019: 21). What makes Industry 4.0 important is that it provides realtime communication and connectivity in the product-machine-human triangle; is also establishing a personalized digital production model. In the model, unlike mass production, the 
concept of a uniform product is abandoned and a personalized production concept is adopted. In addition, thanks to the three-dimensional production tools, users of the product can become the designer and manufacturer of the product at will. At this point, "cyber-physical systems", one of the pillars of Industry 4.0, combining the limitations of the real world with the possibilities of the virtual world come into play.

Industry 4.0 can be defined according to the following eight elements (Hermann, Pentek and Otto, 2015: 8)

1-CPS- Cyber Physical Systems

2-Internet of Things

3-Smart Factory

4-Internet of Services

5-Smart Producs

6-Machine to Machine (M2M)

7-Big Data

8-Cloud Technologies

Cyber Physical Systems: "Cyber physical systems connect the physical world with the virtual computing world with the help of sensors and actuators. SFS, consisting of different founding components, creates global behaviors in cooperation. These components include software systems, communication technologies, sensors / actuators, including embedded technologies, to interact with the real world" (Endüstri40.com). Cyber physical systems expand the communication network with the internet of things. Thus, the aim is to eliminate the borders between the virtual and the real world; this becomes one of the pillars of Industry 4.0.

Internet of Things: "The Internet of Things concept covers systems that are realized through internet sharing of data to meet the human needs of the objects connected to the internet without interacting with people" (Arslan \& Kırbaş, 2016: 2). Using this technology, objects used in daily life will be able to communicate with each other. In this way, the properties of objects such as light, pressure and sound can be observed through sensors, thus gaining the ability to think and make decisions.

Smart Factory: Smart factories are factories that are "smartly produced" without the need for human intervention, using the internet of things and cyber-physical systems.

Internet of Services: The services sector is a growing sector, increasing its speed every day. The growth rate of the sector made it necessary to improve the forms of service and increase their types. For this reason, the sector has been managed through the Internet for a while to cooperate with information technologies. This new system is called "Internet of Services". According to Bartodziej (2017: 54), the internet of services can be defined as webbased software components that provide services that providers have made available on the Internet, according to demand.

Smart Products: In order to qualify an object or product as "smart", the product or object in question must have the ability to communicate with other products or objects in the system in which it is included. Smart products can enter the system without human intervention. Smart products make daily life easier and also increase the quality of life. Based on hybrid robot technology, robotic vacuum cleaners, virtual reality glasses, and scales that work simultaneously with mobile devices, provide weight tracking, are the most known smart products. 
Machine to Machine (M2M): M2M is a communication technology where smart devices communicate autonomously with each other and can make collaborative decisions without human intervention (Chen \& Li, 2012; Igarashi et al., 2012).

Big Data: The development of information and communication technologies has prepared an environment for collecting all kinds of data without testing its scientific and accuracy. The increase in data in terms of type, size and diversity brought the Big Data concept in the media.

Cloud Technologies: These are systems that enable large data stacks to be stored in a virtual environment without space and time restrictions.

\subsection{Applicability, Advantages and Disadvantages of Industry 4.0}

Production in Industry 4.0 process can be explained as a system where machines share real time information with products and provide services. The system is based on internet network and cyber physical systems. It is envisaged that Industry 4.0, that is, the Fourth Industrial Revolution, will be applicable in developed economies approximately twenty years later.

In the news in The Economist magazine, it is stated that many companies in Germany, especially brands such as Bosch, Daimler and Trumpf, have undertakings (Geissbauer, Vedso and Schrauf 2016: 3). Siemens is among the companies that have already adopted the Industry 4.0 process. In addition, Siemens is working on automation-based systems and management processes that envisage the collaboration of wireless information systems. Looking at the studies on Industry 4.0 outside Germany, the USA and other developed European countries attract attention. To Geissbauer, Vedso and Schrauf (2016: 6). According to General Electric in the USA, under the name of "industrial internet", it conducts supporting studies and researches within the scope of Industry 4.0. The United States Government has allocated two billion dollars to support activities in this area under the name of advanced production. In addition, Trumpf Technology Center was established near Chicago in 2015 to support work on Industry 4.0 (MMC, 2017).

In its contacts within the framework of the "European Industrial Renaissance" held in 2014, the European Commission stated that digital technologies are important in raising the efficiency of Europe through redefining business models and creating new products and services (EP, 2015). In the briefing published by the European Parliament in September 2015; By 2020, it is aimed to increase the share of the manufacturing sector in the European Union in total value added up to $20 \%$. In this context, Italy supported research initiatives in the fields of product privatization, re-adjustable factories, high performance and sustainability within the scope of the Fabbrica del Futuro project, carried out between 2011-2013. Britain has pioneered several policies to make manufacturing more flexible, more sustainable, more open to new markets and more committed to a skilled workforce. The most well-known of these is the "Catapult Centers", a high-value production center. These centers help companies reach expert knowledge in special areas such as process management and advanced production. According to the news in the BBC (2018), the artificial intelligence announcer, developed with technology giant Sogou with the Chinese official news agency Shinhua, was introduced at the World Internet Conference in China. "Following the world's first artificial intelligence server developed by China, the first artificial intelligence server started to provide news (SputnikNews, 2019)." Considering all current practices and plans for Industry 4.0, it can be said that Industry 4.0 will provide full integration with the market in developed countries within 15-20 years. 
Studies on Industry 4.0 continue without slowing down, but discussions on the subject continue. The lack of knowledge and skills required for the change and transformation process of Industry 4.0 is among the first topics discussed. It is thought that German companies such as Bosch and Siemens have many years of market experience in the world, will help to overcome the possible shortcomings discussed.

Another discussion topic related to Industry 4.0 is the decrease in the demand for firms with the introduction of smart goods and service production systems. In other words, there are question marks that robots will dismiss people, that is, Industry 4.0 will create employment problems. In fact, if the process is managed correctly, robotic technology has the capacity to facilitate the work of people. Intelligent systems are capable of taking over the daily routines of people. Therefore, it can be said that employment will decrease in blue collar and standard white collar jobs such as accounting, finance, auditing and office services. However, it is clear that the need for human will continue even if it is minimized. The importance of a qualified workforce that can intervene in high-tech systems brought by Industry 4.0 when needed. As a result, it can be said that Industry 4.0 will increase the quality of employment.

\section{MEDIA ORGANIZATIONS AND MANAGEMENT TYPES}

Organizations that operate to produce goods and services and / or put them on the market using production factors to make a profit are called "businesses". Businesses operate to produce economic products and services. Media companies, in other words, media organizations, were established to make profit like other businesses in the market. The most important feature that distinguishes media organizations from other commercial enterprises is that they produce ideas and news. Media organizations can be classified according to the type of activity as follows: Print media companies, magazine companies, newspaper companies, television companies, radio companies and audiovisual media companies.

There are four different management concepts in media companies (Hollified, Becker \& Vlad, 2008: 176):

- International

- Multinational

- Spherical

- Transcend National Borders.

In the international model, the media company develops products and services that will appeal to market demand in the country where it operates. When the conditions are favorable, the said products and services can be marketed abroad. For example, Hollywood industrial cinema was established primarily in accordance with the domestic market of the USA and started to operate in the global market in the post-World War II period. According to Baytar (2011: 63), "As seen in media giants such as Disney, Viacom, Bertelsmann, News Corporation, AOL Time Warner, globalization has caused the financial and capital to cross the national border and become international. As the media markets take on a more fluid and mobile form, multinational and hybrid media giants have begun to form. "In the multinational model, the media organization has subsidiaries in markets abroad. Unlike the global model, in the multinational model, subsidiaries abroad are given broad powers. In the global model, the media organization develops products and services that will appeal to readers and viewers globally. The model, which crosses national borders, structurally combines and creatively coordinates local and global media production. In this model, media organizations produce a variety of culturally and linguistically hybrid media content for television, film and advertising, complementing and contributing to a global consumer culture required for neoliberal capitalism. In line with this new division of creative labor, a new international consumer culture 
popularizes lifestyle identities, culturally close images and individual pleasures. The media structure in question plays an instrumental role in creating masses suitable for mass consumption, individual pleasure and market authority (Artz, 2016).

\section{POSSIBLE CHANGE AND TRANSFORMATION OF THE MANAGEMENT STRUCTURES OF MEDIA ORGANIZATIONS IN INDUSTRY 4.0 PROCESS}

The use of the Internet as a communication tool since the 1970s has initiated a new process in the media that we can call the age of digital communication. The Internet's becoming a social media tool has paved the way for a global information mobility. Thus, electronic devices developed very quickly, and in the simplest terms, mobile phones were used as "smart" devices beyond being phones. Information that has been digitized over time has become digitalized and the production of information has increased substantially. Since digital information is very easy to access and share, it has prepared an environment suitable for the boundary of the news and its spread throughout the world. These developments have been effective in experiencing an important breaking point under the name of globalization of the media. The production, transmission, sharing and storage of information has become possible through digital channels. The digitalization of media contents has enabled traditional media tools to be combined on a single channel using the internet. While the digitalization of the media has not yet fully integrated in the world, we are now meeting a quite different system under the name of Industry 4.0. When Industry 4.0 is fully applicable, extensive changes are expected to occur in the management structures of media outlets. The proposed changes can be listed as follows:

Industry 4.0 brings a new interpretation to the concept of "mass production" that came with the 1st Industrial Revolution. It can be said that we are faced with a new system where personal production can be made thanks to smart production systems. The reflection of personal production in the media can be interpreted as personal news and content production. Using artificial media-oriented media tools, it will be possible to produce content that will appeal to one's interests and expectations.

Three-dimensional reporting can be done with virtual reality glasses. Also, it will be possible for the news to be experienced many times. This situation provides the environment to the person to experience the news he wants without time and space restrictions.

Digitalization of the news will also cause media tools to change form and size. News is already being followed on the internet today. In the new period, we will see that personal belongings can be the news source, closely related to personal news production. In other words, the information will be accessible not only through devices such as phones, tablets, computers, but also through the internet, but through any object we use in daily life. For example, the wristband worn by the person every day, knowing that the person eats eggs for breakfast every day, thanks to the location detection feature, you can understand that the person will have breakfast when he goes to the kitchen at home, with the assumption that he will eat eggs, different breakfast recipes with eggs each day. You can send.

Industry 4.0 also brings the concept of design to an important position. The concept of design is closely related to the wristband sample given in the previous article and the personalized production concepts in the first article. It should attract the attention of consumers in the market that the media tool is to change form and enable the production of customized content, the product to be used as a media tool is convenient and appeals. For example, given the low rate of reading books, magazines and newspapers in underdeveloped countries, the design of a new media tool to be produced in this field is interesting and designed as a usable 
item in daily life, at least in the first stage, the product is also interesting in the market of underdeveloped countries. It can provide.

When all these predictions are evaluated together, it can be said that the globalization of the media and the digitalization of media tools follow a parallel course. With the virtual reality technology in the new period, media organizations will be able to operate independently from time and place. This will make qualified media personnel working in different geographies easily accessible for global media organizations. Therefore, a media institution that wants to serve on a global scale will not have to open branches abroad or employ a staff from abroad within the geographical boundaries in which it operates. This will be the media's interpretation of predictions that Industry 4.0 will reduce production costs.

\section{CONCLUSION}

The Fourth Industrial Revolution, or Industry 4.0, was put on the agenda for the first time at the Hannover Fair held in Germany in 2011. It is foreseen that the Fourth Industrial Revolution will initiate the digital change and transformation process in the entire economy from production to informatics, from communication to security. With Industry 4.0, it is expected that the need for people in the production of goods and services will be minimized, and the intelligent systems based on the internet of things - the internet of services - the cyber physical systems triangle will dominate the production process. It is estimated that Industry 4.0 will achieve market integration in an average of twenty years in developed countries.

Media outlets are economic enterprises operating in the market for profit. With the use of the Internet in the media and information sharing, it is seen that globalization movements in the media have begun. The globalization of the media has enabled media contents to be prepared to appeal to the world.

The Fourth Industrial Revolution allows information to be digitalized and accessible from any channel with internet access. The media sector producing information-based services is among the sectors that are expected to undergo structural changes in Industry 4.0 process. The production of personalized news and content, the development of three-dimensional journalism, the ability to experience the news with virtual reality glasses without time and place constraints, and robotic journalism are the most up-to-date examples of change and transformation in the new period.

In the development of the media from the 1970s to the present, it is seen that media tools have become digital and media contents have become globalized. When the current situation is evaluated in terms of Industry 4.0, it is possible to change the management structures of media organizations in this direction. It is recommended to use personal content production, design and virtual reality concepts during the adaptation of the management approach to Industry 4.0. At this point, it is foreseen that the costs will decrease and the qualified workforce will be more easily accessible. 


\section{REFERENCES}

ALÇIN, S. (2019). “Üretim İçin Yeni Bir İzlek: Sanayi 4.0”. Journal of Life Academics, 3(2), s. 19-30 https://dergipark.org.tr/download/article-file/305119 Date of Access: 07.07.2019

ALTINTAŞ YILMAZ, E. (2018). "Dijital Dönüşüm Uygulamalarının Kurumların Marka Değeri Üzerindeki Etkisi”. Ege Üniversitesi İletişim Fakültesi Medya ve İletişim Araştırmaları Hakemli e-Dergisi, (e-Journal of Ege University Faculty of Communication Media and Communication Research) 2, s. 1-18. https://dergipark.org.tr/download/article-file/464395 Date of Access: 07.07.2019

ARSLAN, K.; KIRBAŞ, İ. (2016). "Nesnelerin İnterneti Uygulamaları İçin Algılayıc1/Eyleyici Kablosuz Düğüm İlkörneği Geliştirme”. Mehmet Akif Ersoy Üniversitesi Fen Bilimleri Enstitüsü Dergisi, (International Journal of Mehmet Akif Ersoy University Institute of Natural Sciences) Özel Sayı $\quad 1, \quad$ s. $35-43$. http://dergipark.ulakbim.gov.tr/makufebed/article/view/5000195368/5000170277 Date of Access: 01.06.2019

ARTZ, L. (2016). "Transnational Media Corporations and the Global Division of Cultural Labor and Consumption". Revue Française des Sciences de l'Information et de la Communication, 17(2), $\quad$ s 25-38 https://www.researchgate.net/publication/315477765_Transnational_Media_Corporati ons_and_the_Global_Division_of_Cultural_Labor_and_Consumption Date of Access: 07.07.2019

BARTODZİEJ, C. J. (2017). "The Concept Industry4.0”. In: The Concept Industry 4.0. Springer Gabler, Wiesbaden, 27-50.

BAYTAR, O. (2011). “Küreselleşme Dinamiklerinin Medya Sektörüne Etkileri”. Hak İş Uluslararası Emek ve Toplum Dergisi, (Hak İş International Journal of Labor and Society) 3, s. 234-261. http://www.ktu.edu.tr/dosyalar/iletisimarastirmalari_1fcea.pdf Date of Access: 01.07.2019

BBC, (2018). "Dünyanın İlk 'Yapay Zeka Spikeri' Ekrana Çıktı”. https://www.bbc.com/turkce/haberler-46138326 Date of Access: 15.04.2019

CHEN, JWM.; LI, F. (2012). "Machine-to-Machine Communications: Architectures, Standards, and Applications". KSII Transactions on Internet and Information Systems, 6(2). $\quad$ https://www.researchgate.net/publication/264846553_Machine-toMachine_Communications_Architectures_Standards_and_Applications Date of Access: 01.06.2019

EP. (2015). "Briefing: Industry 4 - Digitalisation for productivity and growth", European Parliament, Luxembourg, 10s.

Endüstri40.com. "Siber Fiziksel Sistemler". https://www.endustri40.com/siber-fizikselsistemler/ Date of Access: 08.07.2019

GEİSSBAUER, R.; VEDSO, J.; SCHRAUF, S. (2016). “A Strategist's Guide to Industry 4.0”, http://www.strategy-business.com/article/A-Strategists-Guide-to-Industry4.0? gko=7c4cf , Date of Access: 28.11.2016

HARRIS, J. M., (2000). “Sürdürülebilir Kalkınmanın Temel Prensipleri”. Transl. Emine Özete http://www.sdergi.hacettepe.edu.tr/makaleler/EmineOzmet2eviri.pdf Date of Access: 01.06 .2019 
HERMANN, M., PENTEK, T., OTTO, B. (2015). "Design Principles for Industrie 4.0 Scenarios: A Literature Review”. Working Paper, No. 01 / 2015, Technische Universität Dortmund.

HOLLIFIELD, C. A.; BECKER, Lee, B. ve VLAD, T. (2006). "The Effects of Political, Economic and Organizational Factors on the Performance of Broadcast Media in Developing Countries", paper presented to the Political Communication Division of the International Association for Media and Communication Conference, Kahire, Misir.

IGARASHİ, Y., UENO, M., FUJISAKİ, T. (2012). "Proposed Node and Network Models for an M2M Internet”. World Telecommunications Congress (WTC), Mart, s. 1-6.

MMC, (2017). "Trumpf Building Technology Center Near Chicago". Modern Machine Shop http://www.mmsonline.com/news/trumpf-building-technology-center-nearchicago , Date of Access: 22.01.2017

SputnikNews, (2019). "Çin, Dünyanın Yapay Zekalı İlk Kadın Haber Sunucusunu Tanıttı". https://tr.sputniknews.com/bilim/201902211037790208-cin-dunyanin-yapay-zekalikadin-haber-sunucusu/ Date of Access: 10.07.2019

UZKURT, C. (2010). “İnovasyon Yönetimi: İnovasyon Nedir, Nasıl Yapılır ve Nasıl Pazarlanır?” http://www.aso.org.tr/b2b/asobilgi/sayilar/4dosyatemmuzagustos2010.pdf Date of Access: 01.06.2019

WEF, (2018). "Global Competitiveness Report 2018”. World Economic Forum. http://www3.weforum.org/docs/GCR2018/05FullReport/TheGlobalCompetitivenessR eport2018.pdf Date of Access: 02.07.2019

WEF, (2017). "Global Competitiveness Report 2017”. World Economic Forum. http://www3.weforum.org/docs/GCR20172018/05FullReport/TheGlobalCompetitivenessReport2017\%E2\%80\%932018.pdf Date of Access: 02.07.2019 
AKGÜL \& AYER / The Change in the Management Structure of Media Institutions in the Fourth Industrial Revolution (Industry 4.0) Process 